logos_i_ethos_1_(32)_2012,s.63-79

Wojciech Załuski

\title{
O teorii kulturowego doboru grupowego na przykładzie analizy rozwoju chrześcijaństwa w cesarstwie rzymskim
}

Celem niniejszej pracy jest dokonanie oceny sily eksplanacyjnej teorii kulturowego doboru grupowego (dalej: KDG), tj. oceny roli, jaką teoria ta może pełnić w wyjaśnianiu ewolucji kulturowej. Nasza

Wojciech Załuski - dr hab., adiunkt w Katedrze Filozofii Prawa i Etyki Prawniczej Uniwersytetu Jagiellońskiego. Specjalność: filozofia prawa, etyka, filozofia nauki, filozofia religii. analiza będzie przebiegać w dwóch krokach. Pierwszy będzie miał charakter czysto teoretycznej analizy tytułowego zagadnienia; w drugim zilustrujemy naszą analizę konkretnym przykładem zastosowania teorii KDG, próbując pokazać, w jaki sposób można odwołać się do tej teorii w celu wyjaśnienia rozwoju chrześcijaństwa w cesarstwie rzymskim.

\section{Teoria kulturowego doboru grupowego}

Kulturowy dobór grupowy jest teorią mającą na celu wyjaśnienie przebiegu ewolucji kulturowej, tj. przebiegu ewolucji takich artefaktów kulturowych, jak np. idee, reguły, praktyki społeczne ${ }^{1}$. Teorię KDG najpełniej rozwinął Friedrich August von $\mathrm{Hayek}^{2}$, choć nie można uznać go

$1 \quad$ KDG jest pojęciem dwuznacznym: można go rozumieć jako określony mechanizm leżący u podłoża ewolucji kulturowej lub jako sposób wyjaśniania ewolucji kulturowej; w pierwszym przypadku KDG jest elementem rzeczywistości społecznej, w drugim pewną teorią tłumaczącą rzeczywistość społeczną. Rzecz jasna, zwolennicy tezy, że odwołanie się do teorii KSG jest owocną strategią eksplanacyjną będą twierdzić, iż KDG (rozumiany jako określony mechanizm leżący u podstaw ewolucji kulturowej) stanowi element rzeczywistości społecznej.

$2 \quad$ Por. F. A. von Hayek, Knowledge, Evolution and Society, London 1983; tenże, The Fatal Conceit. The Errors of Socialism, London 1988. 
za jej twórcę; idee charakterystyczne dla KDG zostały sformułowane niezależnie przez kilku badaczy ${ }^{3}$. Główne założenie teorii KDG można ująć w następujący sposób: dla dowolnych dwóch artefaktów kulturowych $a_{\mathrm{i}}$, $a_{\mathrm{j}}$, które odnoszą się do tego samego obszaru rzeczywistości i współzawodniczą ze sobą (tj. są wzajemnie sprzeczne lub mają odmienne implikacje praktyczne), ten $z$ nich zostanie zachowany w procesie ewolucji kulturowej, który w większym stopniu sprzyja przeżyciu, bogactwu, reprodukcji i spoistości grupy gotowej go przyjąć. Teoria KDG tłumaczy więc sukces ( $\mathrm{tj}$. rozpowszechnienie się) danego artefaktu kulturowego lub brak takiego sukcesu poprzez konsekwencje, jakie ten artefakt ma dla przetrwania, bogactwa, reprodukcji i spoistości grupy. Warto w tym miejscu wprowadzić pewną dystynkcję, której nie znaleźliśmy w pracach wykorzystujących teorię KDG, a która wydaje się nam użyteczna, mianowicie dystynkcję między dwoma typami wyjaśnień sukcesu (lub jego braku) kulturowych artefaktów za pomocą KDG - wyjaśnieniem niezupetnym i wyjaśnieniem zupełnym. Teoria KDG dostarcza wyjaśnienia niezupełnego, jeśli tłumaczy wyłącznie sukces (czy też brak sukcesu) artefaktu kulturowego, a więc nie tłumaczy przyczyn jego pojawienia się; w przypadku wyjaśnienia niezupełnego zakłada się zatem, że artefakt kulturowy został stworzony czy wynaleziony z innych powodów niż jego oczekiwany, pozytywny wpływ na przetrwanie, bogactwo, reprodukcję i spoistość grupy. Teoria KDG dostarcza wyjaśnienia zupełnego, jeśli tłumaczy zarówno sukces, jak i pojawienie się danego artefaktu kulturowego; wytłumaczeniem pojawienia się danego artefaktu jest właśnie jego oczekiwany, pozytywny wpływ na przetrwanie, bogactwo, reprodukcję i spoistość grupy. Fakt, iż teoria KDG, mimo że została sformułowana w celu wyjaśnienia sukcesu artefaktów kulturowych, może równocześnie wyjaśniać ich genezę, różni ją od teorii doboru naturalnego,

Wśród prekursorów teorii KDG Hayek wymienia (por. The Fatal Conceit, dz. cyt., s. 16) m.in. A. M. Carra-Saundersa (The Population Problem: A Study in Human Evolution, Oxford 1922), A. Allanda (Evolution and Human Behavior, New York 1967) oraz P. Farba (Man's Rise to Civilization, New York 1968). Warto także zwrócić uwagę na podobieństwa między teorią KDG i ewolucyjną epistemologią K. R. Poppera. 
który nigdy nie może wytłumaczyć genezy „materiału” (tj. zróżnicowania genetycznego) będącego przedmiotem doboru naturalnego.

Jak wspomnieliśmy, teoria KDG zmierza do wyjaśnienia przebiegu ewolucji kulturowej przez odwołanie się do pojęcia doboru; musi więc zakładać obecność w procesie ewolucji kulturowej dwóch elementów niezbędnych dla posługiwania się tym pojęciem, mianowicie: zmienności (tj. wielości materiału, z którego tylko część zostaje zachowana w procesie ewolucji) oraz kryteriów doboru (tj. kryteriów określających, co sprawia, że dany materiał zostaje zachowany w procesie ewolucji, a inny nie); w przypadku ewolucji biologicznej kryterium doboru jest następujące: dobór naturalny zachowuje te geny, które w większym stopniu niż alternatywne geny przyczyniają się do przeżycia i reprodukcji swoich „posiadaczy"; natomiast w przypadku ewolucji kulturowej dobór kulturowy zachowuje te artefakty kulturowe, które w większym stopniu niż alternatywne artefakty przyczyniają się do przeżycia, bogactwa, reprodukcji i spoistości grupy (przy czym z czterech wymienionych kryteriów dwa najistotniejsze to przeżycie i reprodukcja, dwa pozostałe można uznać za subsydiarne względem przeżycia i reprodukcji). Friedrich A. von Hayek zwraca uwagę na jeszcze kilka innych cech wspólnych dla procesów ewolucji kulturowej (tak jak jest ona rozumiana na gruncie teorii KDG) i ewolucji biologicznej ${ }^{4}$ : oba procesy są procesami ciągłej adaptacji do zmieniających się i niedających się przewidzieć okoliczności; oba procesy opierają się na zasadzie „współzawodnictwa” między elementami stanowiącymi ich przedmioty; żaden $\mathrm{z}$ tych procesów nie jest oparty na prawach, które pozwalałyby przewidywać w sposób precyzyjny ich przebieg. Jak zauważa von Hayek, ewolucja kulturowa różni się jednak pod wieloma względami od ewolucji biologicznej. W przypadku ewolucji biologicznej przedmiotem doboru są geny, a jednostką doboru gen (lub indywiduum), natomiast w przypadku ewolucji kulturowej przedmiotem doboru są artefakty kulturowe, a jednostką doboru jest grupa. W ewolucji biologicznej źródłem zmienności są mutacje, zmienność powstaje więc $\mathrm{w}$ sposób przypadkowy, niecelowy; natomiast $\mathrm{w}$ ewolucji 
kulturowej źródłem zmienności jest ludzka wynalazczość i twórczość lub przypadek: zmienność powstaje więc na dwa sposoby - nieprzypadkowy, celowy oraz przypadkowy, niecelowy. W procesie ewolucji biologicznej transmisja informacji jest wertykalna: geny są przekazywane tylko od biologicznych rodziców; natomiast w procesie ewolucji kulturowej transmisja informacji jest wertykalna i horyzontalna: członkowie grupy przyswajają sobie artefakty kulturowe w procesach imitacji i uczenia się nie tylko od biologicznych rodziców, lecz także od innych osób spokrewnionych oraz od osób niespokrewnionych (np. grup rówieśniczych). Oczywiście, przekaz informacji w ewolucji biologicznej odbywa się na ścieżce biologicznej, natomiast w ewolucji kulturowej - na ścieżce niebiologicznej; ewolucja kulturowa nie jest więc procesem biologicznym, gdyż, to, co nie jest przekazywane ścieżkami biologicznymi, z definicji nie jest biologiczne. Ponieważ dobór naturalny działa na mutacje powstające w sposób przypadkowy, ewolucja biologiczna przebiega w sposób wolny; natomiast ewolucja kulturowa może być bardzo szybka: nowe artefakty kulturowe pojawiają się często w sposób celowy - w odpowiedzi na określony problem adaptacyjny.

W ramach ogólnej prezentacji teorii KDG należy zwrócić uwagę na jeszcze jeden fakt, mianowicie na konieczność odróżnienia teorii KDG od teorii biologicznego doboru grupowego. W przypadku obu teorii doboru grupowego jednostką doboru jest grupa, o ile jednak w przypadku biologicznego doboru grupowego przedmiotem doboru są geny, o tyle w przypadku KDG przedmiotem doboru są artefakty kulturowe. Ponadto, o ile wśród biologów ewolucyjnych panuje zgoda co do tego, że rola biologicznego doboru grupowego $\mathrm{w}$ tworzeniu adaptacji biologicznych jest pomijalnie niska, o tyle wśród badaczy zajmujących się ewolucją kulturową wciąż toczy się spór o to, jak poważną rolę w kształtowaniu tego procesu odgrywa KDG.

\section{Ocena siły eksplanacyjnej teorii KDG}

Proponujemy następującą definicję operacyjną siły eksplanacyjnej teorii naukowej: siła eksplanacyjna danej teorii jest wprost proporcjo- 
nalna do jej zakresu, tj. liczby zjawisk, które teoria ta może wyjaśnić, oraz odwrotnie proporcjonalna do liczby alternatywnych teorii wyjaśniających przekonująco (przynajmniej prima facie) zjawiska należące do zakresu tej teorii. Definicja ta ma charakter szkicowy, nie podejmujemy próby przedstawienia jej w sposób bardziej precyzyjny. Z definicji tej wynika, że siła eksplanacyjna teorii KDG będzie zależeć od zakresu artefaktów kulturowych, których sukces może być wyjaśniony za pomocą teorii KDG, oraz liczby alternatywnych teorii mogących wyjaśnić sukces tych artefaktów, które należą do zakresu teorii KDG. Siła eksplanacyjna teorii KDG będzie tym większa, im szerszy jest zakres artefaktów, których sukces daje się wyjaśnić za pomocą teorii KDG i im mniejsza jest liczba alternatywnych teorii mogących tłumaczyć sukces artefaktów należących do zakresu teorii KDG. Aby ocenić siłę eksplanacyjną teorii KDG, należy zatem zbadać jej zakres oraz zastanowić się, czy istnieją jakieś przekonujące alternatywne wobec niej teorie tłumaczące przebieg procesu ewolucji kulturowej.

\section{Zakres}

Zakres teorii KDG można próbować definiować mniej lub bardziej szeroko: w najszerszym ujęciu obejmowałby on wszystkie możliwe artefakty kulturowe, w ujęciach węższych - tylko niektóre z nich. Będziemy argumentować, że zakres teorii KDG nie może obejmować wszystkich możliwych artefaktów kulturowych. Jest tak dlatego, że, naszym zdaniem, można wyróżnić kilka klas sytuacji współzawodnictwa artefaktów kulturowych, w przypadku których odwoływanie się do teorii KDG w celu wyjaśnienia sukcesu jednych artefaktów i braku sukcesu innych jest bardzo mało przekonujące. Chodzi o następujące klasy:

(1) Współzawodnictwo idei empirycznie weryfikowalnych (moga być nimi zarówno hipotezy zdroworozsądkowe, jak i hipotezy naukowe) oraz współzawodnictwo idei matematycznych. Wydaje się, że większość przypadków sukcesu lub braku sukcesu tego rodzaju idei można wytłumaczyć, odwołując się do wyjaśnień epistemicznych, tj. wyjaśnień uznających wartości epistemiczne (np. prawdziwość) artefaktów 
kulturowych za kryterium ich sukcesu. Nie oznacza to, że sukces idei empirycznie weryfikowalnych czy idei matematycznych nigdy nie był spowodowany innymi czynnikami niż ich wartość epistemiczna, czy też że tego rodzaju idee nie mają żadnych konsekwencji istotnych z punktu widzenia teorii KDG (tj. nie przyczyniają się do przetrwania, bogactwa, reprodukcji i spoistości grup, które je przyjęły). Istotne jest to, że zwykle idee tego rodzaju są przyjmowane w oparciu o kryteria epistemiczne i że ich walor praktyczny jest zazwyczaj niejako skutkiem ubocznym, a nie bezpośrednim powodem ich przyjęcia.

(2) Współzawodnictwo idei empirycznie nieweryfikowalnych, które nie mają skutków praktycznych istotnych z punktu widzenia teorii KDG. Teoria KDG może wyjaśniać sukces idei empirycznie nieweryfikowalnych, ale nie wszystkich idei tego rodzaju. Nie może wyjaśniać sukcesu idei, które są empirycznie nieweryfikowalne, lecz nie mają skutków praktycznych istotnych z punktu widzenia teorii KDG.

(3) Współzawodnictwo idei empirycznie nieweryfikowalnych majacych identyczne lub bardzo podobne skutki praktyczne istotne z punktu widzenia teorii KDG. Jest jasne, że teoria KDG nie może wyjaśnić sukcesu danego artefaktu kulturowego we współzawodnictwie $\mathrm{z}$ innym artefaktem kulturowym o identycznych czy bardzo podobnych skutkach dla przetrwania, bogactwa, reprodukcji i spoistości grupy.

Podsumowując, zakres teorii KDG nie obejmuje wszystkich możliwych artefaktów kulturowych.

\section{Alternatywne teorie wyjaśniające przebieg ewolucji kulturowej}

Teoria KDG nie jest jedyną teorią mającą wyjaśniać sukces lub brak sukcesu artefaktów kulturowych; do alternatywnych wyjaśnień ewolucji kulturowej można zaliczyć m.in.:

(1) Wyjaśnienia historiozoficzne: sukces danego artefaktu kulturowego wyjaśnia się poprzez odwołanie się do celu czy sensu historii.

(2) Wyjaśnienia epistemiczne: sukces danego artefaktu kulturowego wyjaśnia się tym, że przejawia on określone wartości epistemiczne (np. prawdziwość, wysoki stopień potwierdzenia empirycznego). 
(3) Wyjaśnienia podkreślające rolę historycznego przypadku w sukcesie artefaktów kulturowych. Przez „historyczny przypadek” rozumiemy w tym kontekście zdarzenia niezwiązane bezpośrednio z wartością (epistemiczną czy praktyczną) artefaktów kulturowych, a zatem niebędące egzemplifikacją jakiegoś ogólniejszego mechanizmu mogącego wyjaśnić sukces tych artefaktów (takim zdarzeniem może być np. decyzja władcy o tym, aby nakazać swoim poddanym pod groźbą sankcji przyjęcie określonych przekonań religijnych). Należy jednak zauważyć, że wyjaśnienie sukcesu danego artefaktu kulturowego odwołujące się do historycznego przypadku może stać się częścią wyjaśnienia historiozoficznego; w takim wypadku zdarzenie to nabiera (w ramach owego wyjaśnienia historiozoficznego) głębszego sensu i w istocie traci swój charakter zdarzenia przypadkowego: okazuje się przypadkowe jedynie pozornie.

(4) Wyjaśnienia psychologiczne: sukces danego artefaktu kulturowego tłumaczy się tym, że w większym stopniu niż artefakt względem niego alternatywny zaspokaja określone potrzeby psychologiczne osób będących jego odbiorcami; jeśli owe potrzeby psychologiczne wiążą się - bezpośrednio lub choćby pośrednio - z przetrwaniem, bogactwem, reprodukcją i spoistością grupy, wtedy wyjaśnienie psychologiczne będzie stanowić część wyjaśnienia w oparciu o teorię KDG.

(5) Wyjaśnienie socjologiczne: sukces danego artefaktu kulturowego tłumaczy się pewnymi czynnikami socjologicznymi, np. konformizmem, modą; jedną z wersji wyjaśnień socjologicznych proponuje tzw. szkoła edynburska socjologii wiedzy, która kładzie nacisk na pozaracjonalne - pozaepistemiczne - czynniki decydujące o akceptacji i rozpowszechnianiu idei naukowych.

Podsumujmy dotychczasowe rozważania. Zakres teorii KDG nie jest uniwersalny, tj. nie obejmuje wszystkich możliwych artefaktów kulturowych; istnieją bowiem trzy klasy sytuacji, w których nie ma ona zastosowania (współzawodnictwo idei empirycznie weryfikowalnych/współzawodnictwo idei matematycznych; współzawodnictwo idei empirycznie nieweryfikowalnych, które nie mają skutków praktycznych istotnych z punktu widzenia teorii KDG; współzawodnictwo idei empirycznie 
nieweryfikowalnych mających identyczne lub bardzo podobne skutki praktyczne istotne z punktu widzenia teorii KDG). Nie można jednak automatycznie zakładać, że sukces lub brak sukcesu artefaktów kulturowych nienależących do żadnej z wyżej wyróżnionych klas można przekonująco wyjaśnić, odwołując się do teorii KDG; teoria KDG jest bowiem jedną z wielu teorii tłumaczących przebieg ewolucji kulturowej. Dopiero po dokonaniu dokładnej, empirycznej analizy konkretnego problemu współzawodnictwa dwóch czy więcej artefaktów kulturowych można stwierdzić, czy odwołanie się do KDG jest poprawną strategią wyjaśniającą sukces jednej z nich, czy nie.

Powyższe wnioski uzupełnimy jeszcze o dwa dodatkowe. Po pierwsze, wyjaśnienia $\mathrm{w}$ oparciu o teorię KDG muszą być uzupełnione dokładnym opisem sposobu, $w$ jaki dany artefakt przyczynia się do przetrwania, bogactwa, reprodukcji i spoistości grupy. Tak więc, nawet wtedy, gdy istnieją racje przemawiające za tym, aby przyjąć, iż sukces danego artefaktu kulturowego daje się wyjaśnić za pomocą teorii KDG, nie wystarczy - formułując takie wyjaśnienie - stwierdzić, że ów sukces jest funkcją wpływu, jaki ten artefakt wywarł na przetrwanie, bogactwo, reprodukcję i spoistość grupy, gdyż takie wyjaśnienie byłoby zbyt ogólnikowe. Innymi słowy, w każdym przypadku, w którym tłumaczymy sukces danego artefaktu za pomocą teorii KDG, musimy zawsze uzupełnić nasze wyjaśnienie dokładnym opisem sposobu, w jaki ów artefakt wpłynął na przetrwanie, bogactwo, reprodukcję i spoistość grupy (jest bowiem jasne, że dla różnych artefaktów owe mechanizmy kauzalne mogą być odmienne). Po drugie, teoria KDG rzadko dostarcza zupełnego wyjaśnienia danego artefaktu (tj. wyjaśnienia, które tłumaczy nie tylko sukces danego artefaktu, ale także jego genezę). Zwolennicy teorii KDG oczywiście nie twierdzą, że zadaniem tej teorii jest dostarczenie opisu genezy danego artefaktu kulturowego: teoria KDG została sformułowana dla innego celu, mianowicie wyjaśnienia sukcesu lub braku sukcesu danego artefaktu. Niemniej jednak problem genezy artefaktów kulturowych jest bez wątpienia problemem ciekawym, tak że wyczerpujące wyjaśnienie danego artefaktu wymaga zrozumienia także jego genezy. W ostatnim 
punkcie pracy spróbujemy zilustrować za pomocą przykładu nasze rozważania na temat siły eksplanacyjnej teorii KDG.

\section{Studium przypadku: sukces chrześcijaństwa w cesarstwie rzymskim}

Jako przykład wybraliśmy rozpowszechnianie się chrześcijaństwa w cesarstwie rzymskim i jego ostateczne zwycięstwo nad religiami pogańskimi. Zauważmy na wstępie, że współzawodnictwo chrześcijańskich wierzeń religijnych $\mathrm{z}$ innymi wierzeniami religijnymi nie należy do żadnej z wyróżnionych wcześniej klas sytuacji, w których zastosowanie teorii KDG jest bardzo mało przekonujące (nie jest to bowiem współzawodnictwo idei empirycznie weryfikowalnych/współzawodnictwo idei matematycznych, ani też współzawodnictwo idei empirycznie nieweryfikowalnych, które nie mają skutków praktycznych istotnych z punktu widzenia teorii KDG; wydaje się też, że nie jest to współzawodnictwo idei empirycznie nieweryfikowalnych mających identyczne lub bardzo podobne skutki praktyczne istotne z punktu widzenia teorii KDG - innymi słowy, jak zostanie wykazane w sposób szczegółowy poniżej, skutki praktyczne przyjęcia chrześcijaństwa były wyraźnie odmienne od skutków praktycznych przyjęcia innych wierzeń religijnych obecnych w cesarstwie rzymskim). Nie oznacza to jednak ipso facto, że wyjaśnienie sukcesu chrześcijaństwa za pomocą teorii KDG jest wyjaśnieniem najbardziej adekwatnym; trzeba podać dobre racje przemawiające za przyjęciem tego wyjaśnienia. Jakie więc racje przemawiają za wyjaśnieniem sukcesu chrześcijaństwa w kategoriach KDG? Odpowiadając na to pytanie, będziemy opierać się przede wszystkim na analizach, jakich dostarcza Rodney Stark w swoich pracach poświęconych rozwojowi chrześcijaństwa ${ }^{5}$; Stark wprawdzie nie odwołuje się explicite do teorii KDG, niemniej jego analizy dają się łatwo zinterpretować $\mathrm{w}$ kategoriach tej teorii.

Por. R. Stark, The Rise of Christianity, New York 1997; tenże, Cities of God, New York 2006; tenże, Discovering God, New York 2008. 
Rodney Stark formułuje ogólną uwagę, że sukces mogą odnieść tylko religie, które nie są „wrogie wobec świata” (hostile to the world) i podaje wiele argumentów za tym, że chrześcijaństwo było właśnie taką - nie-wrogą wobec świata - religią. Zwraca uwagę na to, że chrześcijaństwo dostarczało swoim wyznawcom nie tylko czysto duchowych korzyści (głosząc zwycięstwo nad śmiercią i obietnicę wiecznego życia, niosło pocieszenie i nadzieję tym wszystkim, którym życie ziemskie wydawało się nędzne i odarte $\mathrm{z}$ sensu ${ }^{6}$ ), ale także, co szczególnie istotne $\mathrm{z}$ punktu widzenia teorii KDG, korzyści materialnych; innymi słowy, chrześcijaństwo nie tylko dawało obietnicę lepszego życia po śmierci, ale poprawiało życie ludzkie tu i teraz. Fakt, iż chrześcijaństwo dostarczało tych dwóch rodzajów korzyści, przyspieszał jego rozpowszechnianie się, które następowało na dwa główne sposoby - przez konwersje oraz przez relatywnie wysoką (tj. wyższą niż przeciętna w cesarstwie rzymskim) stopę przyrostu populacji gmin chrześcijańskich ${ }^{7}$. Przyjrzyjmy się bliżej tym cechom chrześcijaństwa, które są istotne z punktu widzenia teorii KDG dla wyjaśnienia jego zwycięstwa nad innymi religiami cesarstwa rzymskiego.

Po pierwsze, chrześcijaństwo głosiło etykę seksualną odmienną od dwóch etyk seksualnych, jakie były przyjmowane w cesarstwie rzymskim, mianowicie ascetyzmu seksualnego i (dominującego) permisywizmu

$6 \quad$ Por. np. L. Ferry, Pourquoi la victoire du christianisme sur la philosophie grecque?, [w:] La tentation du christianisme, red. L. Ferry, L. Jerphagnon, Paris 2009, s. 45-113; L. Jerphagnon, Pourquoi le christianisme? Du point de vue des Romains, [w:] La tentation du christianisme, red. L. Ferry, L. Jerphagnon, Paris 2009, s. 13-44.

Według szacunków Starka (The Rise of Christianity, dz. cyt., s. 7) w roku 40 chrześcijaństwo liczyło ok. 1000 wyznawców ( $0.0017 \%$ populacji cesarstwa rzymskiego), w roku 100 ok. 7500 ( $0.0126 \%$ populacji), w roku 200 ok. 218000 (ok. 0.36 populacji), w roku 300 ok. 6 mln (ok. $10 \%$ populacji), a w roku 350 ok. $33 \mathrm{mln}$ (ok. $56 \%$ populacji). Stark twierdzi, że stopa wzrostu populacji chrześcijańskiej była stała (wynosiła ok. 40\% na dekadę), ów wzrost nie był więc jakąś serią „skoków”, dających się wyjaśnić tylko nadprzyrodzoną interwencją czy masowymi konwersjami, lecz procesem ciągłym, dającym się opisać za pomocą krzywej wykładniczej, której dynamika może sprawiać wrażenie zaskakującej, nie ma jednak w sobie nic z „cudu” (tezę, iż dynamiczny wzrost liczebności populacji chrześcijańskiej można wytłumaczyć tylko masowymi konwersjami, głosił np. Adolf Harnack; por. tenże, The Mission and Expansion of Christianity in the First Three Centuries, New York 1908). 
seksualnego. Zwolennicy ascetyzmu seksualnego (przyjmowanego np. przez niektóre sekty gnostyckie i przez manichejczyków) głosili, że seks będąc przejawem cielesności człowieka, zasługuje na potępienie, natomiast zwolennicy permisywizmu seksualnego nie dopatrywali się niczego złego w promiskuityzmie seksualnym, byli pobłażliwi dla niewierności małżeńskiej (przy czym ów permisywizm był jednostronny w tym sensie, że luźne standardy seksualne obowiązywały mężczyzn, a nie kobiety), dopuszczali nieprokreacyjne sposoby uprawiania seksu oraz zachęcali do stosowania różnych metod kontroli urodzeń. Chrześcijaństwo dystansowało się od obu poglądów: zachęcało do seksu, ale podkreślało, że jest dopuszczalny w ramach małżeństwa i że jego celem powinna być prokreacja. Ten pogląd był ściśle powiązany $\mathrm{z}$ innym poglądem charakteryzującym chrześcijańską etykę seksualną, mianowicie tezą o świętości instytucji małżeństwa i rodziny. Oczywiście, religie pogańskie znały instytucje małżeństwa i rodziny; na gruncie jednak żadnej z nich instytucje małżeństwa i rodziny nie cieszyły się takim uznaniem i prestiżem, jak w religii chrześcijańskiej. Otóż nie ulega wątpliwości, że chrześcijańska etyka seksualna była korzystna z punktu widzenia grupowej dynamiki reprodukcyjnej, tj. $\mathrm{w}$ większym stopniu niż dwie pozostałe etyki przyczyniała się do przyrostu liczebności grup, które ją przyjęły. Po drugie, chrześcijaństwo głosząc równość kobiet i mężczyzn, silniej przyciągało do siebie kobiety niż inne religie cesarstwa rzymskiego. Następujący cytat z listu św. Pawła dobrze streszcza doktrynę chrześcijaństwa na temat wzajemnego stosunku małżonków: „Żona nie rozporządza własnym ciałem, lecz jej mąż; podobnie też i mąż nie rozporządza własnym ciałem, ale żona” (1 Kor 7, 2-7). Oczywiście, można w Nowym Testamencie znaleźć cytaty, które wspierają pogląd przeciwny - o wyższości mężczyzny nad kobietą. Niemniej, ogólnie rzecz biorąc, przesłanie Nowego Testamentu w kwestii relacji kobiety i mężczyzny wydaje się być egalitarne; jako takie było też odczytywane w gminach wczesnochrześcijańskich. Należy też wspomnieć, że chrześcijaństwo potępiało instytucję rozwodu, która w społeczeństwie rzymskim osłabiała pozycję kobiety, gdyż przyznawała więcej uprawnień mężczyznom niż kobietom (np. rozwód był dopuszczalny „na życzenie męża”, ale nie „na życzenie kobiety”). Chrześcijaństwo podkreślało także 
warunek dobrowolności małżeństwa. Kobiety-chrześcijanki wychodziły za mąż później niż kobiety-niechrześcijanki ${ }^{8}$, które w związku z tym często nie miały żadnego wpływu na wybór męża - były raczej przedmiotem niż podmiotem kontraktu małżeńskiego, co dodatkowo osłabiało ich pozycję w małżeństwie. $Z$ tych wszystkich powodów pozycja kobiety w małżeństwie chrześcijańskim była o wiele silniejsza niż w małżeństwie pogańskim: w małżeństwie chrześcijańskim kobieta miała większe poczucie bezpieczeństwa i mogła się czuć równa małżonkowi. Status kobiety-chrześcijanki był zresztą wysoki nie tylko w małżeństwie, ale także (choć w mniejszym stopniu) w strukturze kościelnej gminy chrześcijańskiej (kobieta mogła pełnić np. funkcję diakonisy ${ }^{9}$ ). Po trzecie, chrześcijaństwo zakazywało dokonywania aborcji i dzieciobójstwa, które były zjawiskami powszechnymi i tolerowanymi w cesarstwie rzymskim ${ }^{10}$; ich skutkiem było przede wszystkim zmniejszenie odsetka kobiet w populacji cesarstwa oraz obniżenie płodności kobiet: w czasie zabiegów aborcji, przeprowadzanych zwykle w sposób naruszający elementarne zasady higieny, umierało bardzo wiele kobiet, a ofiarą dzieciobójstwa były częściej dziewczynki niż chłopcy; zabiegi aborcji były też jedną z ważnych przyczyn niskiej płodności kobiet w cesarstwie rzymskim ${ }^{11}$. Biorąc pod uwagę dwa wymienione wyżej fakty (chrześcijańska doktryna o równości kobiety i mężczyzny, silna pozycja kobiety w małżeństwie chrześcijańskim, zakaz dzieciobójstwa i aborcji), nie może zaskakiwać to, że o ile w całym cesarstwie rzymskim stosunek liczebny mężczyzn do kobiet wynosił 1,4:1, o tyle w gminach chrześcijańskich liczba kobiet przewyższała liczbę mężczyzn (co więcej, jak twierdzi Stark, płodność kobiet-chrześcijanek była przypuszczalnie wyższa niż kobiet-niechrześcijanek ${ }^{12}$ ). Zważywszy nosiła 12 lat.

W prawie rzymskim dolna granica wieku dla zawarcia małżeństwa przez kobietę wy-

$9 \quad$ Por. H. Chadwick, Kościół w epoce wczesnego chrześcijaństwa, tłum. A. Wypustek, Warszawa 2004, s. 29-41.

10 Dzieciobójstwo jest jedną z mrocznych kart nie tylko starożytnego Rzymu, ale także starożytnej Grecji.

${ }_{11}$ Np. Prawo XII Tablic dopuszczało dzieciobójstwo dziewczynek (także zdrowych) i zdeformowanych lub słabych chłopców.

12 Por. R. Stark, The Rise of Christianity, dz. cyt., s. 127. 
jednak na to, że chrześcijaństwo potępiało promiskuityzm seksualny, owa nadwyżka kobiet $\mathrm{w}$ gminach chrześcijańskich nie miałaby znaczenia dla zwiększania liczebności gmin chrześcijańskich, gdyby chrześcijaństwo zakazywało zawierania małżeństw egzogamicznych przez kobiety chrześcijańskie z poganami. Otóż czwartym czynnikiem przyczyniającym się do rozpowszechniania chrześcijaństwa było właśnie to, że dopuszczało ono egzogamiczne małżeństwa. W rezultacie chrześcijaństwo pozostało, jak podkreśla Stark, „otwartą siecią" (open network) ${ }^{13}$, która utrzymywała więzi z osobami „z zewnątrz", dzięki czemu dynamika przyrostu jego wyznawców mogła się utrzymywać na stałym - wysokim - poziomie. Wskutek małżeństw egzogamicznych chrześcijaństwo przenikało do wyższych warstw społeczeństwa rzymskiego, gdyż kobiety chrześcijańskie często poślubiały arystokratycznych wyznawców religii pogańskiej, a następnie wychowywały swoje dzieci w wierze chrześcijańskiej. Ta otwartość chrześcijaństwa na potencjalnych wyznawców z różnych kręgów etnicznych, a więc jego ponadetniczny charakter (czym różniło się np. od judaizmu), była jednym z kluczowych czynników sprzyjających rozpowszechnianiu się chrześcijaństwa ${ }^{14}$. Po piąte, chrześcijańska etyka miłosierdzia przyczyniała się do wzmacniania społecznych więzi między członkami gmin chrześcijańskich i zachęcała do wstępowania do tych gmin. Etyka miłosierdzia była oryginalnym wkładem chrześcijaństwa w historię refleksji etycznej; etycy starożytni nie cenili takich cnót, jak miłosierdzie, litość, współczucie, i nigdy nie zbudowali opartej na nich etyki. Etyka ta miała uzasadnienie teologiczne, po pierwsze, w nauce, że ponieważ Bóg kocha każdego człowieka, ludzie nie mogą Go zadowolić, jeśli nie kochają swoich bliźnich (por. Mt 25, 35-40) oraz, po drugie, w nauce, że Bóg kocha tych, którzy Go kochają; te teologiczne tezy były całkowicie obce religiom pogańskim $^{15}$. Chrześcijańska etyka miłosierdzia miała szczególne znaczenie

13 Por. tamże, s. 115.

14 Warto w tym miejscu zauważyć, że K. R. Popper umieszcza właśnie wczesne chrześcijaństwo w tradycji doktryn głoszących ideały społeczeństwa otwartego - ideały humanitaryzmu, braterstwa i altruizmu; por. K. R. Popper, The Open Society and Its Enemies, Princeton 1950, s. 219-221.

Por. R. Stark, The Rise of Christianity, dz. cyt., s. 212. 
w sytuacji, w jakiej wielokrotnie znajdowało się cesarstwo rzymskie - sytuacji rozpadu więzi społecznych wskutek katastrof naturalnych i wojen. Stark szczególnie podkreśla rolę, jaką w sukcesie chrześcijaństwa mogły odegrać epidemie, które wielokrotnie nawiedzały cesarstwo rzymskie (np. epidemia ospy w latach 165-180 pociągnęła za sobą śmierć ok. 1/3-1/4 całej populacji cesarstwa, w tym cesarza Marka Aureliusza); właśnie w takich skrajnych sytuacjach chrześcijaństwo mogło jeszcze silniej, niż w zwykłych okolicznościach wykazać swoją praktyczną wyższość nad innymi religiami: chrześcijaństwo nie tylko pozwalało efektywniej walczyć ze skutkami epidemii (gdyż motywowało swoich wyznawców do wzajemnej pomocy), ale także dostarczało teologicznego wyjaśnienia tych epidemii, pozwalając dostrzec w nich jakiś nadprzyrodzony sens, i tym samym łatwiej je zaakceptować. Owa efektywna walka z różnymi nieszczęściami, jakie dotykało mieszkańców cesarstwa (należy dodać do nich nieszczęście chroniczne, jakim był chaos, ubóstwo, brutalność życia miejskiego ${ }^{16}$ ), polegała na rozwijaniu przez gminy chrześcijańskie nowych relacji społecznych, opartych na zasadach solidarności społecznej, na budowaniu czegoś w rodzaju, jak pisze Paul Johnson, „miniaturowego welfare state w cesarstwie, które generalnie było pozbawione systemu pomocy społecznej"17 (w gminach chrześcijańskich oferowano pomoc osobom chorym, sierotom, wdowom). Trafna więc wydaje się opinia R. Starka, że chrześcijaństwo było „ruchem rewitalizacyjnym (revitalization movement) w cesarstwie rzymskim"18.

Biorąc pod uwagę wymienione wyżej cechy chrześcijaństwa (prokreacyjna etyka seksualna wraz z doktryną o świętości rodziny i małżeństwa, doktryna o równości kobiet i mężczyzn, zakaz aborcji i dzieciobójstwa, otwarty charakter, oraz etyka miłosierdzia ${ }^{19}$, a także ich skutki

16 Por. tenże, Cities of God, dz. cyt., s. 25-62 oraz J. Pelikan, The Excellent Empire: The Fall of Rome and the Triumph of the Church, New York 1989, s. 21.

17 P. Johnson, A History of Christianity, New York 1976, s. 75.

18 R. Stark, The Rise of Christianity, dz. cyt., s. 75.

19 Warto zauważyć, że dwie z pięciu wymienionych cech chrześcijaństwa mają rodowód judaistyczny: chodzi o prokreacyjną etykę seksualną wraz z doktryną o świętości małżeństwa i rodziny oraz zakaz aborcji i dzieciobójstwa; pozostałe są oryginalnym wkładem chrześcijaństwa. 
społeczne (przewaga grup chrześcijańskich nad grupami niechrześcijańskimi ${ }^{20}$, jeśli chodzi o zdolność przetrwania, spoistość grupową, dynamikę reprodukcyjną), można chyba powiedzieć, że teoria KDG w istotnym stopniu wyjaśnia sukces chrześcijaństwa w cesarstwie rzymskim. Analiza przyczyn sukcesu chrześcijaństwa z perspektywy teorii KDG prowadzi też do ogólniejszego wniosku, że chrześcijaństwo (wbrew np. tezom Edwarda Gibbona ${ }^{21}$ ), nie było przyczyną kryzysu cesarstwa rzymskiego, lecz odpowiedzią na ten - ideologiczny i materialny - kryzys. Nie ulega jednak wątpliwości, że wyjaśnienie sukcesu chrześcijaństwa w oparciu o teorię KDG nie jest całkowite, tj. wskazujące na wszystkie kauzalnie istotne czynniki decydujące o tym sukcesie; wyjaśnienie całkowite (które jest oczywiście jedynie pewną ideą regulatywną) musiałoby uwzględnić także inne teorie tłumaczące sukces idei chrześcijańskich; na zakończenie naszych rozważań wspomnimy o kilku tego rodzaju teoriach.

Po pierwsze, to, że skupiliśmy się na roli KDG w sukcesie chrześcijaństwa, nie oznacza, że pomniejszamy rolę czysto doktrynalnych aspektów chrześcijaństwa, tj. tych jego założeń teologicznych, które nie mają skutków istotnych z punktu widzenia teorii KDG; otóż walory doktryny chrześcijańskiej (które, w zależności od punktu widzenia badacza, będą określane różnie, np. jako jej piękno, głębia, prawdziwość, sugestywność, czy po prostu jako jedynie nowość na tle innych wierzeń religijnych cesarstwa rzymskiego) na pewno w dużej części tłumaczą sukces chrześcijaństwa. Po drugie, nie można w wyjaśnieniu sukcesu chrześcijaństwa pomijać teorii psychologicznej. W jednej z tych wersji wskazuje ona na duchowe korzyści płynące $\mathrm{z}$ chrześcijaństwa, a polegające np. na zaspokajaniu potrzeby sensu; powierzchowna religia

20 Należy jednak podkreślić, że rozważania na temat sukcesu chrześcijaństwa prowadzone w niniejszym artykule skupiają się przede wszystkim na przyczynach, które sprawiły, że chrześcijaństwa zastąpiło klasyczną religię pogańską. Analiza przyczyn zwycięstwa chrześcijaństwa nad innymi kultami wschodnimi (np. mitraizmem) to temat na odrębny artykuł. Warto jednak dodać w tym miejscu, że przyczyny te są w istotnym zakresie podobne, tzn. chrześcijaństwo głosiło etykę, która miała korzystniejsze skutki dla przetrwania i reprodukcji grupy. Miało też bardziej otwarty charakter niż zwykle ezoteryczne kulty wschodnie.

${ }^{21}$ Por. E. Gibbon, The Decline and Fall of the Roman Empire, Chatham, Kent 1988 (1776-1788). 
pogańska tę potrzebę zaspokajała w nieporównanie mniejszym stopniu: na jej gruncie relacje między człowiekiem i bogami miały charakter interesowny, nie-intymny, podczas gdy na gruncie chrześcijaństwa relacje między człowiekiem i Bogiem mają charakter intymnej więzi. Inna wersja teorii psychologicznej, Nietzscheańska, stwierdza, że chrześcijaństwo było wyrazem uczucia ressentiment - uczucia mściwości i zazdrości przemieszanego z poczuciem własnej niższości - charakterystycznego dla klas najniższych cesarstwa rzymskiego ${ }^{22}$. Pierwsza daje się pogodzić z wyjaśnieniem za pomocą teorii KDG; co więcej, ponieważ pojęcie duchowych korzyści jest często trudne do rozdzielenia od pojęcia materialnych korzyści, można ją traktować jako część wyjaśnienia w oparciu o KDG (np. wiara w nieśmiertelność dawała pocieszenie, a jednocześnie mogła motywować do praktykowanie miłosierdzia także wtedy, gdy wiązało się z nim ryzyko choroby czy śmierci, np. w czasie epidemii). Wersja Nietzscheańska wydaje się być z nią jednak sprzeczna: trudno uwierzyć, że do praktykowania etyki miłosierdzia, wymagającej wiele samodyscypliny i zdolności do samo-poświęcenia, byliby zdolni ludzie ogarnięci ressentiment. Wersja ta nie daje się też pogodzić z ustaleniami historyków na temat „klasowej bazy” wczesnego chrześcijaństwa. Wbrew tezom Nietzschego (a także badaczy z kręgów marksistowskich, np. Engelsa) chrześcijaństwo rekrutowało swoich wyznawców przede wszystkim z klas średnich, a nie spośród klas najuboższych czy niewolników ${ }^{23}$; chrześcijaństwo nie było więc religią „starożytnego proletariatu" czy religią ludzi ogarniętych ressentiment. Po trzecie, nie można pominąć także teorii podkreślających rolę przypadku w sukcesie idei religijnych. Teza, że sukces chrześcijaństwa daje się całkowicie wyjaśnić jakimś ciągiem zdarzeń przypadkowych (np. epidemie w cesarstwie, konwersja Konstantyna Wielkiego ${ }^{24}$ ), wydaje się zupełnie nieprzekonująca. Trudno jednak się nie zgodzić z tym, że pewne zdarzenia

22 Por. F. Nietzsche, Zur Genealogie der Moral, München 1988 (1887), s. 83-142.

23 Por. R. Stark, The Rise of Christianity, dz. cyt., s. 29-47.

24 Por. na ten temat np. M. Simon, A. Benoît, Giudaismo e cristianesimo, tłum. A. Giardina, Roma 2005, s. 288-316. 
przypadkowe (np. wspomniane epidemie) mogły istotnie przyczynić się do sukcesu chrześcijaństwa, choć, jak się wydaje, nie były tego sukcesu ani warunkiem wystarczającym, ani koniecznym ${ }^{25}$. Po czwarte, kolejną grupą teorii są teorie historiozoficzne, które zakładają, że sukces chrześcijaństwa był jakoś uprzednio wyznaczony przez sens czy cel historii, tak czy inaczej (teologicznie lub świecko) rozumiany. Tego rodzaju teorie należą już jednak do filozofii historii, a nie do nauk społecznych; pozostając na gruncie nauk społecznych, nie można bronić poglądu, że zwycięstwo chrześcijaństwa było nieuniknione czy w jakiś sposób pre-determinowane. Podsumowując, teoria KDG wydaje się dostarczać przekonującego, choć na pewno nie całkowitego, wyjaśnienia źródeł sukcesu chrześcijaństwa. Wniosek ten, jak sądzimy, można uogólnić: jako że wierzenia religijne mają zwykle wiele różnorakich skutków, które są istotne z punktu widzenia teorii KDG, teoria ta może ze szczególnym powodzeniem wyjaśniać przebieg i wynik ich współzawodnictwa ${ }^{26}$. Należy jednak pamiętać, że wyjaśnienia sukcesu określonych idei odwołujące się do teorii KDG najczęściej nie są ani całkowite (tzn. aby wyjaśnić sukces tych idei w sposób całkowity, tj. uwzględniający wszystkie czynniki kauzalnie istotne, trzeba odwołać się także do innych teorii), ani zupełne (tzn. nie tłumaczą genezy tych idei).

25 Przeciwnego zdania wydaje się być R. Stark, który pisze, że „[...] gdyby klasyczne społeczeństwo nie zostało zniszczone i zdemoralizowane przez te katastrofy [Stark ma na myśli epidemie - W. Z.], chrześcijaństwo mogłoby nigdy nie stać się dominującą wiarą" (The Rise of Christianity, dz. cyt., s. 74).

26 Podobny pogląd przyjmuje D. S. Wilson w książce Darwin’s Cathedral: Evolution, Religion, and the Nature of Society, Chicago 2003. 